\title{
Determination of Users' Knowledge on the Impact of Organic Chemicals in Interior Equipment Elements on Health: Ankara/Turkey Sample
}

\author{
Kemal Yildirim ${ }^{*}, 1$ and Feray Ünlü ${ }^{2}$ \\ ${ }^{I}$ Department of Furniture and Decoration, Faculty of Technical Education, Gazi University, 06500, Beşevler, Ankara, \\ Turkey \\ ${ }^{2}$ Department of Interior Architecture and Environmental Design, Faculty of Fine Art, Design and Architecture, Attlim \\ University, 06836, Incek Gölbaşl, Ankara, Turkey
}

\begin{abstract}
This study aims to determine the knowledge of users in Ankara according to gender, age and educational background, regarding the hazardous effects on human health of organic chemicals dispersed into the environment from interior equipment elements. The study group consisted of 92 randomly-selected people. The survey, developed in line with the aim of the study, was given to this sample. It was found that participants do not have sufficient knowledge about the organic chemicals dispersed into the environment from interior equipment elements. It was found that young people have less knowledge than middle-aged, and secondary-education graduates have less knowledge than higher-education graduates. It was determined that the user's knowledge can be increased, the use of hazardous materials in fabrication manufacturing can be decreased, and that awareness raising activities should be conducted.
\end{abstract}

Keywords: Interior design, furniture, human health, organic chemicals.

\section{INTRODUCTION}

In recent years, most users in Turkey tend to purchase fabrication products for furniture or decoration elements as in other countries. Advantages of fabrication products, such as wide selection of colors, designs, product variety, low price, and off-the-shelf availability, influence users' choice. Despite these advantages, hazardous chemicals that are dispersed into the environment from equipment elements used in manufacturing processes adversely affect users' health. This leads to the question: to what extent do users have knowledge about adverse effects of hazardous gases emanating from equipment elements on their own health? Taking stand from this point, this study aims to determine the knowledge of consumers about these hazardous chemicals which directly affect their health.

Chemical contaminators that are released from construction materials can bring significant damage to human health in the event of long-term and continuous contact. Thiermeyer [1] reports that contact with these hazardous chemicals for eight hours a day and during a 40 hours a week damage human health. Furthermore, the World Health Organization reports that people spend $90 \%$ of their time indoors $[2,3]$. Considering this fact, it can be seen that the abovementioned hours can be easily exceeded and exposure to hazardous materials is likely. A healthy human needs to breathe $15 \mathrm{~m}^{2}$ fresh air on average [4]. The US Environmental Protection Agency reports that interior air

*Address correspondence to this author at the Department of Furniture and Decoration, Faculty of Technical Education, Gazi University, 06500, Beşevler, Ankara, Turkey; Tel: +90 31220288 29; Fax: +90 31221200 59; E-mail: kemaly@gazi.edu.tr pollution is 2 -10 times more than external environment pollution [5]. On the other hand, one of the factors that affect interior air is external air pollution [6]. External air penetrates into the interior, based on construction materials.

The construction industry began activity on energy consumption and production after the energy crisis in the mid-1970s. Insulation used for low energy consumption minimized ventilation rates in buildings. For this reason; however, interior air pollution gained relevance. The use of wood, marble and natural fibers was replaced by particle boards, synthetic fibers and plastics. These products are final petroleum products and each of them can release and accumulate in interior air when production occurs over certain temperatures. The emissions of volatile organic chemicals in walls, ceilings and floor laying, furniture, carpets, fabrics, insecticides, computers, copy machines, personal care products used inside and biowastes, can cause damage to human health. These contaminators adversely affect interior air quality and cause various health problems. The results of interior chemical emission sources detected by Dr. Bill Wolverton [7-14] are presented in Table 1.

As can be seen in the above table, people who are exposed to artificial materials used in interior equipment elements such as particle board, fiber board, laminated flooring, and PVC, can have structural changes/damages to the human body and cells such as mucous membrane (irritation in eye, nose, throat, skin), erythema, general symptoms (headache, fatigue, vertigo, nausea, concentration impairment), respiratory difficulties etc. For this reason, the choice of materials and use of indoor equipment elements are highly important [3]. At this point, we should give a brief description of indoor equipment elements-sourced contaminators which are contacted via respiration. 
Table 1. Chemical Emission Sources

\begin{tabular}{|c|c|c|c|c|c|c|c|}
\hline Chemical Emission Sources & Formaldehyde & $\begin{array}{l}\text { Xylene/ } \\
\text { Toluene }\end{array}$ & Benzene & TCE & Ammoniac & Alcohol & Acetone \\
\hline Adhesive Materials & $\mathrm{x}$ & $\mathrm{x}$ & $\mathrm{x}$ & - & - & $\mathrm{x}$ & - \\
\hline Biologic Substances & - & $\mathrm{x}$ & - & - & $\mathrm{x}$ & $\mathrm{x}$ & $\mathrm{x}$ \\
\hline Carpets and Fabrics & $\mathrm{x}$ & - & - & - & - & $\mathrm{x}$ & - \\
\hline Bonding Elements & $\mathrm{x}$ & $\mathrm{x}$ & $\mathrm{x}$ & - & - & $\mathrm{x}$ & - \\
\hline Interior Coating & $\mathrm{x}$ & $\mathrm{x}$ & $\mathrm{x}$ & - & - & $\mathrm{x}$ & - \\
\hline Cosmetic Products & - & - & - & - & - & $\mathrm{x}$ & $\mathrm{x}$ \\
\hline Printers and Printed Materials & - & $\mathrm{x}$ & $\mathrm{x}$ & $\mathrm{x}$ & $\mathrm{x}$ & - & - \\
\hline Particle Boar & $\mathrm{x}$ & $\mathrm{x}$ & $\mathrm{x}$ & - & - & $\mathrm{x}$ & - \\
\hline Plywood & $\mathrm{x}$ & - & - & - & - & - & - \\
\hline Painting and Varnish & $\mathrm{x}$ & $\mathrm{x}$ & $\mathrm{x}$ & - & - & $\mathrm{x}$ & - \\
\hline Tobacco Smoke & $\mathrm{x}$ & - & $\mathrm{x}$ & - & - & - & - \\
\hline
\end{tabular}

TCE: Trichloroethylene.

\subsection{Organic Chemicals in Interior Equipment Elements}

Interior contaminators generally consist of carcinogenic substances, mutagens (substances that result in genetic changes), teratogens (substances that result in birth defects), viruses, bacteria, and allergens. Interior contaminators, which can cause significant damages to human health, can be found in 3 forms $[2,3,15,16]$. These are; Gases (flammable gases, nonpersistent gases and hazardous gases), Particles (suspended particles, bacteria, fungi, viruses) and Radiation. These interior contaminators are briefly explained below.

\subsubsection{Gases}

\subsubsection{Flammable Gases}

These gases are released from gas-burning cookers and heaters, wood and coal smoke from stoves and fireplaces, fuel oil used in heating and cigarette smoke. Flammable products such as natural gas, petroleum, wood and coal are not efficient and can be dangerous for interior use. Flammable gases released from these fossil fuels and insulation materials generate carbon monoxide, sulfur dioxide, and nitrogen dioxide [2].

Carbon dioxide: When it reaches $1000 \mathrm{ppm}$ indoors, health problems can occur. Headaches, loss of appetite, eye, nose and throat irritation, and upper respiratory irritation symptoms can occur [6].

Carbon monoxide: Interior exhaust smoke and stoves are the main sources of carbon monoxide. It can also be found in cigarette smoke. Coal and wood smoke from interior stoves and fireplaces can also be fatal $[2,3,6]$. Wood smoke contains some carcinogenic substances. Coal smoke contains high levels of sulphurdioxide and rains over the city as acid. Isolated primary and secondary fuel stoves are more environment-friendly and safe [2, 3]. People exposed to wood smoke can have upper respiratory irritation and chronic pulmonary diseases [6]. Carbon monoxide poisoning emerges with unclear symptoms such as vertigo, nausea and confusion and can be fatal with increased levels of poisoning $[2,3]$. Headaches, allergies, loss of consciousness, and effects related to the cardiovascular system can also be observed [6]. There can also be failures in the psychomotor system, visual problems and effects to the central neural system [4].

Sulphurdioxide: This gas is generated from sulphur burning within solid and liquid fuels. These fuels used in house and workplace heating appliances are significant sulphur dioxide sources in urban settings. Sulphurdioxide can lead to eye irritation and coughing [4], upper and lower respiratory infections, and asthma and pulmonary infections, especially in children $[2,3]$.

Nitrogen dioxide: This gas is released from gas burning cookers and heaters $[2,3]$. Most of the research concludes that nitrogen dioxide influences pulmonary functions [17].

\subsubsection{Nonpersistent Gases}

Nonpersistent gases can penetrate into interiors from the external environment and into the paint of the house from chlorine in water [6]. It comes from construction materials especially interior paint, vanish, and adhesive, flooring. Copy machines and some office materials can be available in office environment $[15,18]$. Nonpersistent gases, such as xylene and toulen, are found in gypsum blocks and panels used in wall construction. Ethylbenzene, formaldehyde and toulen are used in plastering. Toulen is also a component of wallpapers. Ethyllbenzene, trimethylbenzene, and xylene can diffuse into interior air through materials used in interior surface plating such as processed wood and artificial wood, paint, varnish etc. [15]. They can lead to eye and respiratory irrigation, vertigo, headaches, nausea and cancer [6]. They have effects such as abirritation, headaches and fatigue, and on the central system of people exposed to low concentrations, and can lead to respiratory diseases and asthma as well. Benzene, toulen, ethyllbenzene, xylene and stiren are the most hazardous nonpersistent gases [19]. Their high-concentration effects intensify and can even lead to coma and death [20].

Most of nonpersistent gases are released from petrochemical substances. They turn into nonpersistent gases 
at room temperature or below room temperature; accumulate in the air and become hazardous. The most hazardous of these mixed nonpersistent gases are formaldehyde, organochloride and phenolic components $[2,3]$.

Formaldehyde: This gas is the most commonly found hazardous substance in interior assessments because it generally emits from materials used in interior furniture. Other source materials of interior formaldehyde emissions are aminoplast foam, cigarette smoke, direct fire sources, gas ovens, paints, wood protector substances and disinfection substances [21]. Formaldehyde is commonly used in industry as a glue and protector substance and therefore it can be found in home products and building materials-pressed wood plates such as wood particle boards, fiber boards, laminated massive boards and ply boards, paper products, upholstery fabrics, carpets, cosmetic products $[2,3]$, concrete structure [15], and prefabricated houses [6]. Scientific research demonstrates that excessive formaldehyde emission leads to skin, eye, nose and throat irrigation, respiratory difficulties, nosebleeds, headaches, nausea, fatigue and most importantly, it has carcinogenic effects $[2,3,6]$.

Organochlorine: The adverse effects of hydrocarbons and chlorine on health and the environment are well-known. These effects are poisonous potential carcinogenic substances which react with live fatty tissues composing life cycle. These hazardous organochlorines are PVC (polyvinylchloride) and more carcinogenic PCBs (polychlorinated biphenyls) which disseminate hazardous gases. Hundreds of plastics in the form of hard, soft, liquid, dust, board or film forms are used almost everywhere indoors. Soft plastics are more hazardous as they disseminate gases into stored foods. PVCs are the worst. They can lead to still births, cancer, chronic bronchia and skin diseases. It is reported that acrylics containing acrylonitrile such as polyethylene are also carcinogenic. Polystyrene gases can irrigate eyes, nose and throat and can lead to vertigo. To summarize, many plastics release fatal poisoning smoke and gases $[2,3]$.

Phenolic Components: Phenols are aromatic components which bond to an aromatic ring or one or more hydroxyl groups in terms of chemical structure. They are pure, colorless or white-pink crystal solids. They can form plastic by means of polymerizing with phenol formaldehyde. Pure phenols or those containing carbolic acid are strong irrigating disinfectants. Phenols are found in polishers, detergents, fabric and carpet cleaners, air cleaners, ammonia, turpentine, naphthalene, sodium hydroxide, acetone, and chlorine. Paint, varnish, paint remover, dissolver and diluter, and adhesive materials used indoors release hazardous organic chemicals, which contain gas concentrations of dried substances. Metals in paints are very hazardous as well. These hazardous gases which diffuse into the air can easily penetrate into skin and lungs. These hazardous gases release chlorofluorocarbon into the atmosphere and thus bring damage to the ozone layer. In 1987, more than 40 countries have signed Montreal Convention, which restricts the use of CFC $[2,3]$.

\subsubsection{Hazardous Gases}

Ozone: In addition to the safe ozone, this gas can turn into a hazardous ozone due to the processes that it was exposed to in the atmosphere. Hazardous ozone diffuses into the atmosphere from motor vehicle and industrial activities; it releases volatile organic components (VOC) and nitrousoxide (NOX). Especially in summer, high amount of ozone is generated with the effect of sunlight [4]. Some fuels used with interior heaters, electromagnetic devices such as printers, copy machines, computers etc. can generate ozone. Respiration of high concentrations of ozone can cause respiratory problems and severe asthma in children, the elderly, people with respiratory distress and even healthy people [3, 16]. Throat irritation, coughs, chest pain, and inflammation in internal surfaces of the lungs can occur [4].

Radon: The main source of exposure to interior radon is related to the geographical structure of region and the effect level can differ according to construction material and building [6]. High level of interior radon equals to the thousands of chest x-rays that people have annually [22]. It is a severe contaminator, which is diffused from construction materials such as granite and lime stone with the deterioration of uranium under natural conditions and from sub-layers of the earth from well water and emmisions into the air. Radon gas, which is present in underground soil, construction materials and elements with undergroundsourced raw materials such as brick and natural stone, can lead to lung cancer $[3,16]$.

\subsubsection{Particles}

Suspended particles, bacteria, fungi and viruses can be found in house dust, human and animal hairs and skin rashes, fabric fibers, furniture and construction materials, the interior of buildings with good insulation, central heating buildings and cleaners [6]. Especially in carpets, dust, bacteria and mold can be formed. Molds forming in basements, bathrooms, window sills, laundry drying rooms, water leakages and floods can affect the neural system and immune system. In most of new construction materials, molds and bacteria can be formed within a couple of days [22]. They can cause allergic reactions and affect eye and the upper respiratory system. Humidity control, cleaning and airing decrease the rate of these particles. The interior human capacity can be resolved with maximum seven people per $100 \mathrm{~m}^{2}[6]$.

\subsubsection{Radiation}

Radioactive substances release alpha, beta and gamma rays and generate electromagnetic rays; these rays are known as radiation. Electromagnetic is an energy that can release everywhere in the form of waves or particles. Its natural source is sun rays. It is released indoors from microwaves, the radio and television. Electromagnetic particles have an energy that can break chemical bonds, they can also damage cells, breakdown DNA and can lead to cancer [22].

\section{METHODS}

\subsection{Research Group}

The research group consisted of 92 users who were living in the Ankara province of Turkey and were randomly selected from a large population representing 43 different professions and different ages, gender and educational background. With regards to the characteristics of the participants; $57.6 \%$ were female (53 people), $42.4 \%$ were 
male (39 people), $54.3 \%$ were secondary school graduates (50 people), $25 \%$ were between the ages of 18-29 (23 people), $50 \%$ were between the ages of $30-45$ (46 people), and $25 \%$ were in $46+$ age group ( 23 people).

\subsection{Survey Design}

Valid and reliable surveys of previous relevant studies were beneficial for the design of the present survey and this detailed survey measured the research hypothesis. Closeended question, multiple choice and multi-option question methods were used. In the first stage of the survey, questions were asked to measure the general knowledge of participants and questions in the second stage measured knowledge level. Statistical assessments of each factor from the survey questions are represented below.

\subsection{Application of the Survey}

The survey was developed in line with the aim of the study. It was applied with by face-to-face interviewing and aimed to determine the knowledge level of participants regarding the hazardous effects of organic chemicals on human health in interior equipment elements. The survey was applied to participants in July (2013) at different times on weekdays and weekends. Participants completed the survey within approximately 20 minutes.

\subsection{Statistical Assessment}

This study was conducted with 92 participants living in Ankara and dependent and independent variables, which comprised the research hypothesis, were tested with suitable statistical methods. To this end, research data's arithmetic means and standard deviation values of were calculated. The One Way ANOVA test was used to determine whether differences between variables at $p<0.05$ level was statistically significant or not. 'SPSS' Statistics and 'Microsoft Office Excel' programs were used to evaluate the data.

\section{RESULTS}

The "Cronbach Alfa" was used to test the reliability of dependent variables in order to determine the participants' knowledge level regarding the hazardous effects of organic chemicals released from interior equipment elements on human health and the test results are presented in Table $\mathbf{2}$. Accordingly, the research scale's reliability coefficient, consisting of nine factors, was 0.928. In their studies, Bagozzi and Yi [23], McKinley, Manku-Scott, Hastings, French, and Baker [24], Bosma, Marmot, Hemingway, Nicholson, Brunner, and Stansfield [25], Grewal, Krishnan, Baker, and Borin [26] and Kim and Jin [27] reported that a scale can be considered to be "reliable" if the alpha reliability coefficient is over 0.70 . It can be seen that this research's Cronbach Alpha coefficient is above the mentioned value. Accordingly, the present research scale can be regarded as "reliable."

The data regarding the extent of knowledge of organic chemicals in interior equipment elements based on the participants' gender, the categorical means and the standard deviation, are given in Table $\mathbf{3}$.

The obtained data presented in graphic form in Fig. (1), in order to compare the differences between the evaluations of organic chemicals used in interior equipment elements for the variance sources, was found to be significant in the analysis of variance and the mean values of the differences between the participants according to gender.

According to Fig. (1), the assessment of female and male participants regarding adverse effects of organic chemicals in interior equipment elements (discussed under nine titles) on human health are parallel with each other; however, there are some differences between the knowledge levels of female and male participants for factors A1, A2, A5, A6 and A7. Accordingly, the ANOVA test was used to determine the differences between the knowledge levels of female and male participants regarding the effects of organic chemicals emitted from interior equipment elements on human health. Accordingly, a statistically significant difference was found for factor A1 $(F=6.952 ; d f=1 ; p=0.010)$ at the level of $\mathrm{p}<0.05$. On the other hand, no statistically significant difference was found for the following factors: $\mathrm{A} 2(F=2.531$; $d f=1 ; p=0.115), \mathrm{A} 3(F=0.087 ; d f=1 ; p=0.482), \mathrm{A} 4(F=$ $0.334 ; d f=1 ; p=0.565), \mathrm{A} 5(F=1.964 ; d f=1 ; p=0.165)$, $\mathrm{A} 6(F=3.052 ; d f=1 ; p=0.084), \mathrm{A} 7(F=0.602 ; d f=1 ; p=$ $0.440), \mathrm{A} 8(F=0.055 ; d f=1 ; p=0.814)$ and $\mathrm{A} 9(F=0.043 ; d f=$ $1 ; p=0.837)$ at the level of $\mathrm{p}<0.05$. To conclude, it was

\section{Table 2. Reliability Analysis of Dependent Variables}

\begin{tabular}{|c|c|c|}
\hline Dependent Variables & Item Reliability & Scale Reliability \\
\hline A1: I know the components of materials used in unhealthy interior equipment elements. & 0.922 & \multirow{6}{*}{0.928} \\
\hline A3: I know health problems occurring in people who are exposed to bad interior air quality. & 0.922 & \\
\hline $\begin{array}{l}\text { A4: I know that hazardous interior chemicals diffuse in air depending on ambient temperature and can bring } \\
\text { severe damages to human health. }\end{array}$ & 0.920 & \\
\hline A6: I know hazardous gases releasing from interior walls, ceiling, floor covering. & 0.921 & \\
\hline A7: I know hazardous gases releasing from interior paints and varnish. & 0.918 & \\
\hline $\begin{array}{l}\text { A8: I know poisoning gases releasing from materials used in pressed wood plates such as particle boards, fiber } \\
\text { boards, laminated massive plates and ply boards, paper products, fabrics, carpets and many other areas. }\end{array}$ & 0.916 & \\
\hline
\end{tabular}


Table 3. The Mean and Standard Deviation of the Dependent Variables

\begin{tabular}{|c|c|c|c|c|c|c|}
\hline \multirow{3}{*}{ Dependent Variables } & \multicolumn{6}{|c|}{ Gender of Laypersons } \\
\hline & \multicolumn{2}{|c|}{ Female } & \multicolumn{2}{|c|}{ Male } & \multicolumn{2}{|c|}{ Total } \\
\hline & $\bar{X}^{\text {a }}$ & SD & $\bar{X}$ & SD & $\bar{X}$ & SD \\
\hline A1 & 3.37 & 1.03 & 3.12 & 1.23 & 3.48 & 1.16 \\
\hline A2 & 3.92 & 1.20 & 3.51 & 1.25 & 3.75 & 1.23 \\
\hline $\mathbf{A 3}$ & 3.07 & 1.20 & 3.00 & 1.21 & 3.04 & 1.20 \\
\hline A4 & 3.26 & 1.24 & 3.10 & 1.42 & 3.19 & 1.31 \\
\hline A5 & 3.86 & 1.12 & 3.51 & 1.29 & 3.71 & 1.20 \\
\hline A6 & 3.86 & 1.11 & 3.43 & 1.25 & 3.68 & 1.18 \\
\hline A7 & 3.30 & 1.33 & 3.07 & 1.42 & 3.20 & 1.37 \\
\hline $\mathbf{A 8}$ & 3.75 & 1.29 & 3.69 & 1.19 & 3.72 & 1.25 \\
\hline A9 & 3.92 & 1.29 & 3.87 & 1.08 & 3.90 & 1.20 \\
\hline
\end{tabular}

Note: $\overline{\boldsymbol{X}}$ : Mean value, $\mathrm{SD}=$ Standard deviation

a: Means of the variables listed between 1-5 (large numbers are negative responses).

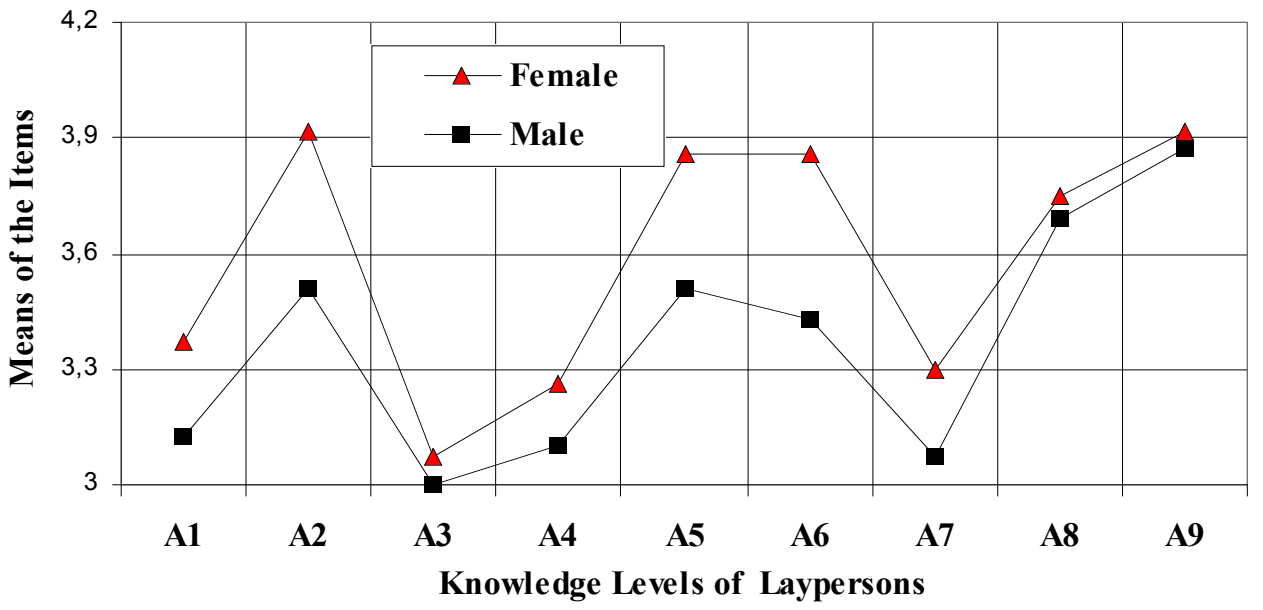

Note: Means of the variables listed between 1-5 (large numbers are negative responses).

Fig. (1). The evaluations of the organic chemicals in the interior equipment elements based on the gender of the laypersons.

found that no statistically significant difference was found between participant assessments according to gender at the level of $\mathrm{p}<0.05$ except for the A1 factor. Moreover, according to the mean values in Table $\mathbf{3}$, participants did not have sufficient knowledge about the organic chemicals released into the environment from interior equipment elements.

The data for the extent of knowledge of organic chemicals in interior equipment elements based on the participants' age, the categorical means and the standard deviation, are given in Table 4.

The obtained data presented in graphic form in Fig. (2), in order to compare the differences between participants' evaluations of organic chemicals used in interior equipment elements for the variance sources, was found to be significant in the analysis of variance and the mean values of the differences with regard to the age of the participant.
According to Fig. (2), assessments of young and older participants regarding adverse effects of organic chemicals released from interior equipment elements (discussed under nine titles) on human health are parallel with each other; however, there are some differences between knowledge levels in terms of age for factors A2, A3, A5, A7, A8 and A9. Accordingly, the ANOVA test was used to determine the differences between knowledge levels of young and older participants regarding the effects of organic chemicals released from interior equipment elements on human health. Accordingly, no statistically significant difference was found for factors $\mathrm{A} 1(F=0.075 ; d f=2 ; p=0.928), \mathrm{A} 2(F=0.424 ; d f=$ $2 ; p=0.656), \mathrm{A} 3(F=0.437 ; d f=2 ; p=0.647), \mathrm{A} 4(F=0.135$; $d f=2 ; p=0.874), \mathrm{A} 5(F=0.397 ; d f=2 ; p=0.673), \mathrm{A} 6(F=$ $0.095 ; d f=2 ; p=0.910), \mathrm{A} 7(F=0.512 ; d f=2 ; p=0.601)$, $\mathrm{A} 8(F=0.863 ; d f=2 ; p=0.425)$ and $\mathrm{A} 9(F=1.215 ; d f=2 ; p=$ $0.302)$ at the level of $p<0.05$. To conclude, according to the differences in participants' assessments according to age, 
Table 4. The Mean and Standard Deviation of the Dependent Variables

\begin{tabular}{|c|c|c|c|c|c|c|c|c|}
\hline \multirow{3}{*}{ Dependent Variables } & \multicolumn{8}{|c|}{ Age of Laypersons } \\
\hline & \multicolumn{2}{|c|}{$18-29$} & \multicolumn{2}{|c|}{$30-45$} & \multicolumn{2}{|c|}{$46+$} & \multicolumn{2}{|c|}{ Total } \\
\hline & $\bar{X}^{\mathbf{a}}$ & SD & $\bar{X}$ & SD & $\bar{X}$ & SD & $\bar{X}$ & SD \\
\hline A1 & 3.56 & 1.23 & 3.47 & 1.13 & 3.43 & 1.19 & 3.48 & 1.16 \\
\hline $\mathbf{A 2}$ & 3.95 & 1.22 & 3.67 & 1.23 & 3.69 & 1.29 & 3.75 & 1.23 \\
\hline A3 & 3.00 & 1.27 & 3.15 & 1.26 & 2.86 & 1.01 & 3.04 & 1.20 \\
\hline A4 & 3.21 & 1.24 & 3.13 & 1.30 & 3.30 & 1.45 & 3.19 & 1.31 \\
\hline A5 & 3.52 & 1.27 & 3.78 & 1.19 & 3.78 & 1.20 & 3.71 & 1.20 \\
\hline A6 & 3.73 & 1.25 & 3.63 & 1,142 & 3.73 & 1.25 & 3.68 & 1.18 \\
\hline A7 & 3.26 & 1.48 & 3.30 & 1.29 & 2.95 & 1.42 & 3.20 & 1.37 \\
\hline A8 & 3.86 & 1.35 & 3.80 & 1.10 & 3.43 & 1.40 & 3.72 & 1.25 \\
\hline A9 & 4.04 & 1.36 & 4.00 & 1.11 & 3.56 & 1.19 & 3.90 & 1.20 \\
\hline
\end{tabular}

Note: $\overline{\boldsymbol{X}}:$ Mean value, $\mathrm{SD}=$ Standard deviation.

a: Means of the variables listed between 1-5 (large numbers are negative responses).

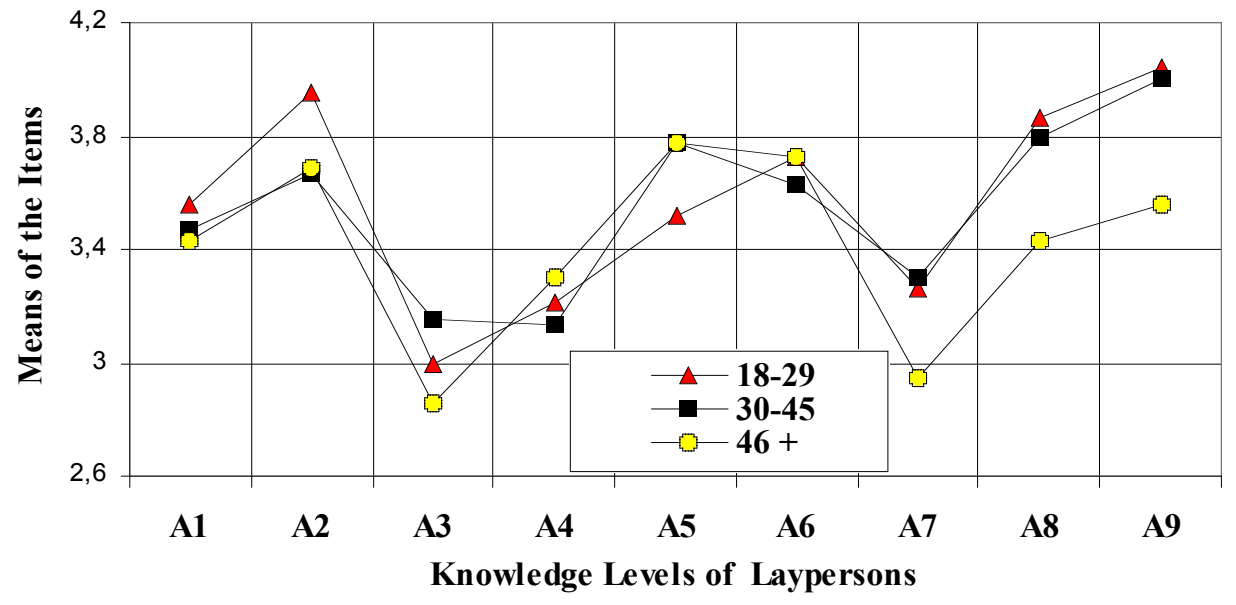

Note: Means of the variables listed between 1-5 (large numbers are negative responses).

Fig. (2). The evaluations of the organic chemicals in interior equipment elements based on the age of the participant.

young people have less information about organic chemicals in interior equipment elements than older people for factors A1, A2, A3, A7, A8 and A9.

The data for the extent of knowledge of organic chemicals in interior equipment elements based on the education levels of the participants, the categorical means and the standard deviation, are given in Table $\mathbf{5}$.

The obtained data presented in graphic form in Fig. (3), in order to compare the differences between the evaluations of organic chemicals used in interior equipment elements for the variance sources, was found to be significant in the analysis of variance and the mean values of the differences between participants' education levels.

According to Fig. (3), assessments of secondary and higher school graduate participants regarding the adverse effects of organic chemicals in interior equipment elements (discussed under nine titles) on human health are parallel with each other; however, there are some differences between knowledge levels based on educational level for factors A1, A2, A5, A6, A7, A8 and A9. Accordingly, the ANOVA test was used to determine the differences based on educational level for participants' knowledge levels regarding the effects of organic chemicals emitted from interior equipment elements on human health. Accordingly, a statistically significant difference was found for factor A1 $(F=4.414 ; d f=1 ; p=0.038)$, at the level of $\mathrm{p}<0.05$. On the other hand, no statistically significant difference was found for factors A2 $(F=1.621 ; d f=1 ; p=0.206), \mathrm{A} 3(F=0.302 ; d f=$ $1 ; p=0.584), \mathrm{A} 4(F=0.122 ; d f=1 ; p=0.727), \mathrm{A} 5(F=0.710$; $d f=1 ; p=0.402), \mathrm{A} 6(F=1.217 ; d f=1 ; p=0.273), \mathrm{A} 7(F=$ $2.526 ; d f=1 ; p=0.115), \mathrm{A} 8(F=0.543 ; d f=1 ; p=0.463)$ ve $\mathrm{A} 9(F=2.546 ; d f=1 ; p=0.114)$ at the level of $\mathrm{p}<0.05$. Accordingly, no statistically significant difference was found between participants' assessments with regard to educational background at the level of $\mathrm{p}<0.05$ except for factor A1. To conclude, according to the differences in the participants' assessments based on educational level, secondary school 
Table 5. The Mean and Standard Deviation of the Dependent Variables

\begin{tabular}{|c|c|c|c|c|c|c|}
\hline \multirow{3}{*}{ Dependent Variables } & \multicolumn{6}{|c|}{ Education Levels of Participants } \\
\hline & \multicolumn{2}{|c|}{ Secondary } & \multicolumn{2}{|c|}{ Higher } & \multicolumn{2}{|c|}{ Total } \\
\hline & $\bar{X}^{\text {a }}$ & SD & $\bar{X}$ & SD & $\bar{X}$ & SD \\
\hline A1 & 3.76 & 1.03 & 3.26 & 1.22 & 3.48 & 1.16 \\
\hline $\mathbf{A 2}$ & 3.92 & 1.13 & 3.60 & 1.30 & 3.75 & 1.23 \\
\hline A3 & 3.11 & 1.08 & 2.98 & 1.30 & 3.04 & 1.20 \\
\hline A4 & 3.14 & 1.29 & 3.24 & 1.34 & 3.19 & 1.31 \\
\hline A5 & 3.83 & 1.14 & 3.62 & 1.25 & 3.71 & 1.20 \\
\hline A6 & 3.83 & 1.22 & 3.56 & 1.14 & 3.68 & 1.18 \\
\hline A7 & 3.45 & 1.27 & 3.00 & 1.42 & 3.20 & 1.37 \\
\hline A8 & 3.83 & 1.18 & 3.64 & 1.30 & 3.72 & 1.25 \\
\hline A9 & 4.11 & 1.21 & 3.72 & 1.17 & 3.90 & 1.20 \\
\hline
\end{tabular}

Note: $\overline{\boldsymbol{X}}$ : Mean value, $\mathrm{SD}=$ Standard deviation.

a: Means of the variables listed between 1-5 (large numbers are negative responses).

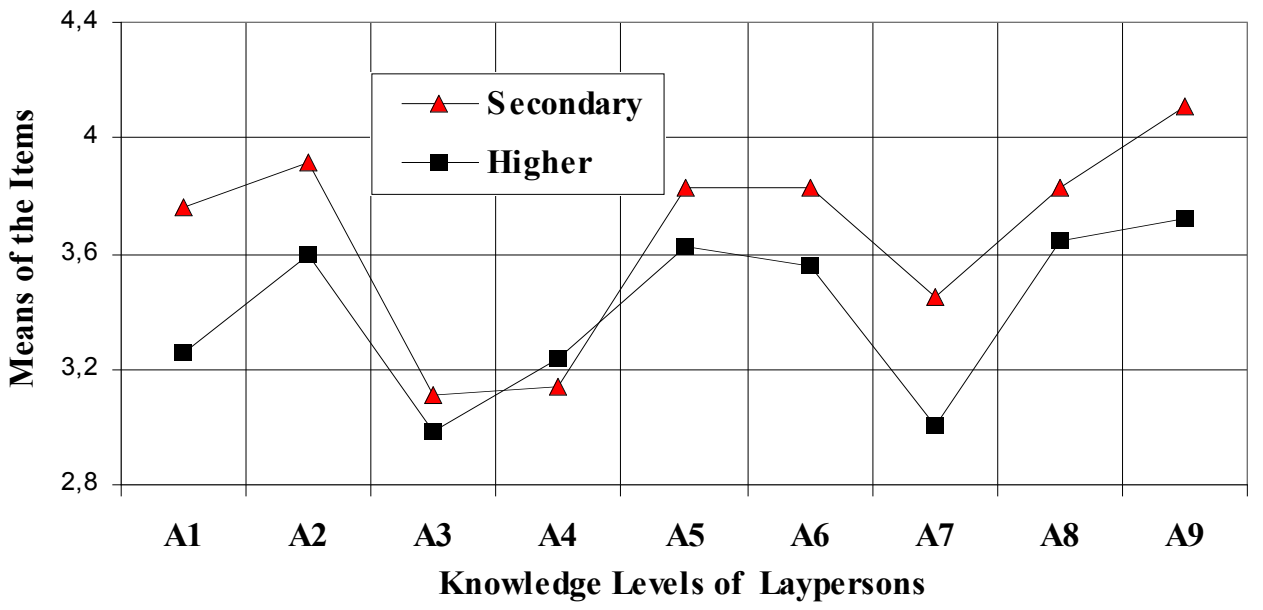

Note: Means of the variables listed between 1-5 (large numbers are negative responses).

Fig. (3). The evaluations of the organic chemicals in the interior equipment elements based on the education levels of the laypersons.

graduates have less information than higher school graduates about organic chemicals in interior equipment and furniture elements for factors A1, A2, A3, A5, A6, A7, A8 and A9.

To summarize, according to abovementioned mean values, participants do not have sufficient knowledge about the hazardous organic chemicals released into the environment by interior equipment elements.

\section{CONCLUSIONS AND DISCUSSIONS}

This study found that participants do not have sufficient knowledge about the organic chemicals released into the environment by interior equipment elements. Knowledge on these organic chemicals are significant for health-wise for everybody that users must be informed and increase awareness on the subject. Users must be aware of the organic chemicals in interior equipment elements their health threats and in order to raise the future generations in better environment and healthier we must raise them well inform the general public.
In this research primarily, it was found that gender does not make a significant information difference. On the other hand, the accumulation of knowledge is related to age; young people between the ages of 18-29 have less information about organic chemicals in interior equipment elements than those in the $30+$ group. According to this finding, with the purpose of providing more information to young people, necessary arrangements should be made in curriculums, and all segments of community should be education by written materials and visual media. Due to fact that information about these chemicals are not included in the elementary education syllabus we may conclude that age group between 18-29 are not informed about the subject. Once the awareness on the organic chemicals used in interior equipment elements and their health hazards have been increased, the general public may have individuals whom are more aware and inform on the health hazards that people may make more conscious choices that will improve the productions of the building industry. General public need to 
be knowledged and be aware to have sustainable production, better life quality with consumption and life cycle of the products.

Another factor that affects knowledge about organic chemicals is education level. This study found that secondary school graduates have less information about organic chemicals released into the environment by interior equipment elements than higher school graduates. In this framework, awareness raising activities should be conducted with regard to the conformity of interior equipment elements, especially according to the E1 and B1 norms of European Union Quality Standards, both for producers and consumers. The E1 norm is related to gas emissions from furniture and decoration elements and B1 form is related to burning threshold of materials used in these elements. These two norms are very important when determining the safety of interior equipment elements for human health. Our country has limited amount of information and research on the subject to increase the awareness and information that there is no specific law on the subject. Also only some laws and regulations that may be associated with the subject that state must create new laws and regulations to protect the human health from the chemicals that are released from the interior equipment elements.

To summarize, it can be seen that there is a direct correlation between energy production-consumption relationship and interior contaminators. For this reason, renewable energy use and material production, which serve as sources for this energy, gain importance. The main reason for the use of construction and equipment materials that contain organic chemicals is their low costs and easy construction. Their gas emissions and effect levels on health are directly correlated to the amount of use and temperature increase. In order to reduce their unhealthy effects, the use of materials containing organic chemicals should be reduced. The use of these materials should also be audited, and awareness raising activities should be performed for designers, users and producer companies. Further studies should investigate the effects of curriculums addressing these issues in universities and on university students. This way new syllabus can be developed and improved that future generations whom will decide for these industrial products will be informed and aware of the materials that are used for the interior equipment elements. Awareness of the consumer will cause the hazardous materials to vanish from the market that this will diminish the health problems that are caused by the chemicals that governments spending to cure health issues caused by these products will decrease. Building industry may neglects the general public's health in order to earn more profits. It is very important to inform the general public to encourage them to make more conscious and aware choices for the construction materials.

\section{CONFLICT OF INTEREST}

The authors confirm that this article content has no conflict of interest.

\section{ACKNOWLEDGEMENTS}

Declared none.

\section{REFERENCES}

[1] Thiermeyer M. Klimazone. AIT 1994; 10: 198.

[2] Pearson D. The natural house book. London: Conran Octopus Limited 1989.

[3] Yildirim K. Bitkilerin iç mekân kirleticileri üzerindeki etkileri. İçmimar Dergisi 2013; 28: 107-15.

[4] Tecer LH. Hava kirliliği ve sağlığımız. Bilim ve Aklın Aydınlığında Eğitim 2011; 135: 15-29.

[5] Ohura T, Amagi T, Shen XL, Zhang P, Zhu L. Comperative study on indoor air quality in Japan and China: Characteristics of residential indoor and outdoor VOCs. Atmos Environ 2009; 43: 6352-59.

[6] Vaizoğlu SA, Tekbaş ÖF, Evci D. Kapalı ortam hava kalitesinin sağlığa etkisi. Sted 2000; 1-5.

[7] Wolverton BC, Kozaburo T. Plants: Why you can't live without them. New Delhi: Roli Books 2010.

[8] Wolverton BC. Eco-friendly houseplants. London: Weidenfeld \& Nicolson 1996.

[9] Wolverton BC, Wolverton JD. Interior plants: Their influence on airborne microbes inside energy-efficient buildings. J Mississippi Acad Sci 1996; 41: 99-105.

[10] Wolverton BC, Wolverton JD. Plants and soil microorganismsremoval of formaldehyde, xylene and ammonia from the indoor environment. J Mississippi Acad Sci 1993; 38: 11-5.

[11] Wolverton BC, Wolverton J, Eds. Bioregenerative life support systems for energy-efficient buildings. Proceedings of International Conference of Life Support and Biospherics; Huntsville, Alabama 1992.

[12] Wolverton BC, Johnson A, Bounds K. Interior landscape plants for indoor air pollution abatement. NASA/ALCA Final Report, Plants for Clean Air Council. Davidsonville, Maryland 1989.

[13] Wolverton BC, McDonald RC, Mesick HH. Foliage plants for the indoor removal of the primary combustion gases carbon monoxide and nitrogen oxides. J Mississippi Acad Sci 1985; 30: 1-8.

[14] Wolverton BC, McDonald RC, Watkins Jr. EA. Foliage plants for removing indoor air pollution from energy-efficient homes: Econ Botany 1984; 38: 224-8.

[15] Vural SM, Balanlı A. Yapı ürünü kaynaklı iç hava kirliliği risk değerlendirmede ön araştırma. YTÜ Mimarlık Fakültesi Dergisi 2005; 1: 28-39.

[16] Yurtseven E. İki farklı coğrafi bölgedeki ilköğretim okullarında iç ortam havasının insan sağlığına etkileri yönünden değerlendirilmesi. İstanbul: İstanbul Üniversitesi Sağlık Bilimleri Enstitüsü 2007.

[17] Güler Ç, Çobanoğlu Z. Kimyasallar ve çevre. Ankara: Sağlık Bakanlığı 1997.

[18] Lee C, Dai Y, Chien C, Hsu D. Characteristics and health impacts of volatile organic compounds in photocopy centers. Environ Res 2006; 100: 139-49.

[19] Lee S, Lam S, Fai H. Characterization of UOBs, ozone, and PM10 emissions from office equipment in an environmental chamber. Build Environ 2001; 36: 837-42.

[20] Sandmeyer E. Cyclic hydrocarbons. In: Clayton GD, Clayton FE, Eds. Patty's industrial hygiene and toxicology. New York: Wiley 1982; pp. 3253-431.

[21] Duygulu İ. İç mekânlarda yapı malzemelerine bağlı hava kirliliği. Mimarlık 1996; 269: 39-41.

[22] Baker-Laporte P, Elliot E, Banta J. Prescriptions for a healty house: A practical guide for architects, builders and homeowners. Beverly Hills: Pomegranate Press 2008.

[23] Bagozzi RP, Yi Y. On the evaluation of structural equation models. J Acad Market Sci 1988; 16: 74-94.

[24] McKinley RK, Manku-Scott T, Hastings AM, French DP, Baker R. Reliability and validity of a new measure of patient satisfaction with out of hours primary medical care in the United Kingdom: development of a patient questionnaire. BMJ 1997; 314: 193-8. 
[25] Bosma H, Marmot MG, Hemingway H, Nicholson AC, Brunner E, Stansfield SA. Low job control and risk of coronary heart disease in Whitehall II (prospective cohort) study. BMJ 1997; 314: 558-65.

[26] Grewal D, Krishnan R, Baker J, Borin N. The effect of store name, brand name and price discounts on consumers' evaluations and purchase intentions. J Retailing 1988; 74: 331-52.
[27] Kim JO, Jin B. Korean customers' patronage of discount stores: Domestic vs multinational discount store shoppers' profiles. J Consum Market 2001; 18: 236-55.

(C) Yildirim and Ünlü; Licensee Bentham Open.

This is an open access article licensed under the terms of the Creative Commons Attribution Non-Commercial License (http: //creativecommons.org/licenses/by$\mathrm{nc} / 3.0 /$ ) which permits unrestricted, non-commercial use, distribution and reproduction in any medium, provided the work is properly cited. 